\title{
マルチロータ型ヘリコプタの汎用的な機体設計手法と低コストによる実現*
}

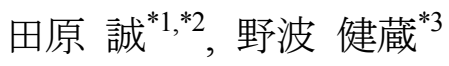

\section{General Airframe Design and Implementation with Low-Cost for Multi-Rotor Type Helicopters}

\author{
Makoto TAWARA*1 and Kenzo NONAMI \\ ${ }^{* 1}$ Graduate School of Engineering, Chiba University \\ 1-33, yayoi, inage, chiba, Chiba 263-8522, Japan
}

Recently, Quad-rotor type helicopters which are representative of Multi-rotor type helicopters have been extensively developed over the world. The Multi-rotors are expected to replace Single-rotor type helicopters as an industrial helicopter because of their simplicity of the structure and good maintainability. In this paper, we focused on the operation problems of previous industrial helicopters and applied the Multi-rotors by a generalized design method. The generalization of the design method is performed considering variation of requirements of airframe specifications. In addition, we considered using commercial components rather than customized components in each process, so we achieved cost reduction compared with previous study. At first, we introduce the required specifications of a small pesticide application in this study and present the airframe design method. And then, we tuned parameters with presented simulation model and implement a multi-rotor type helicopter following the design method. Finally, we show the flight result and present the effectiveness of the design method.

Key Words : Moving Robot, Maneuverability, Modeling, Autonomy, UAV, MAV, Multi-Rotor, Airframe Design

\section{1. 緒言}

近年, UAV(Unmanned Aerial Vehicle), MAV(Micro Air Vehicle)などの無人航空機の研究が活発に行われている. 弚の中でも無人ヘリコプタは, ホバリング (空中停止) や垂直離着陸など他の航空機にはない特徵的な飛行形態を 有しており，農薬散布，空中撮影，防災監視，空中測量などの用途に期待されている．代表的な機体であるシング ルロータ型ヘリコプタにおいては自律制御での運用も実用化されており，農薬散布や空中撮影の業務に用いられ ている.シングルロータ型ヘリコプタの自律制御に関しては既に樣々な研究がなされており ${ }^{(1)(2)(3)}$, 本研究グルー プでも独自のアプローチによる成功を収めている ${ }^{(4)(5)}$. しかしながら , シングルロータ機はスワッシュコントロー ルをはじめとする複雑な機構によって飛行を可能としているため, 修理やメンテナンスには熟練した技術が必要 となる.さらに，機構部の開発は各機体専用の設計となるため, 要求仕樣が異なる業務に対して適切な機体を投入 する場合，開発コスト，開発期間が大きくなるといった問題点を抱えている．弚のため，小規模な範囲の薬斉散布 にも大型機が用いられるといった運用が行われており，採算性やリスクマネジメントにおいて問題となっている． 無人ヘリコプタには樣々な種類が存在し，図 1 に示すように可変ピッチ機構を有するものと有しないものに分類 される . 前者はシングルロータ型ヘリコプタや二重反転型ヘリコプタが該当する . スワッシュプレートを用いた可 変ピッチ機構を有するのか特徵で, サイクリックピッチコントロールとコレクティブピッチコントロールによって 飛行を実現している.一方で, 近年の半導体の小型化, バッテリの高密度化，モータ技術の進歩により，固定ピッ チ式のマルチロータ型ヘリコプタが注目を浴びている . 各ロータの回転数差を利用して飛行を実現するというシ

\footnotetext{
* 原稿受付 2011 年 12 月 18 日

*1 正員, 千葉大学大学院工学研究科（干263-0022 千葉県千葉市稲毛区弥生町 1-33）

*2 ヒロボー(株) 研究開発所 (下726-0006 広島県府中市桜が丘 3-3-1)

*3 正員, フェロー, 千葉大学大学院工学研究科（广263-0022 千葉県千葉市稲毛区弥生町 1-33）

E-mail: makoto-tawara@graduate.chiba-u.jp
} 


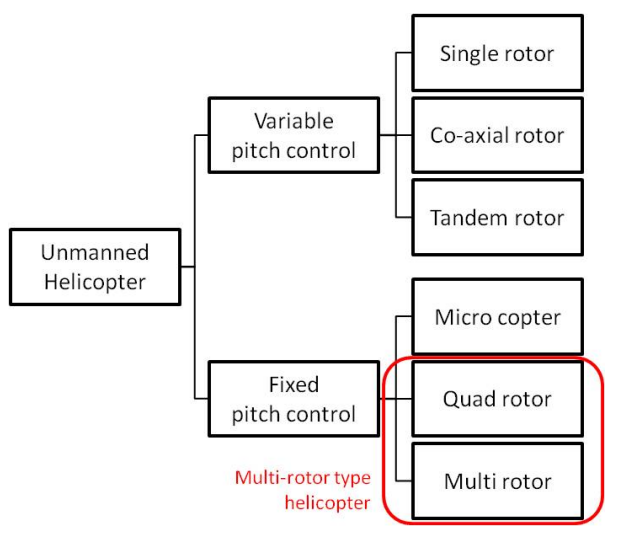

Fig. 1 Classification of unmanned helicopters

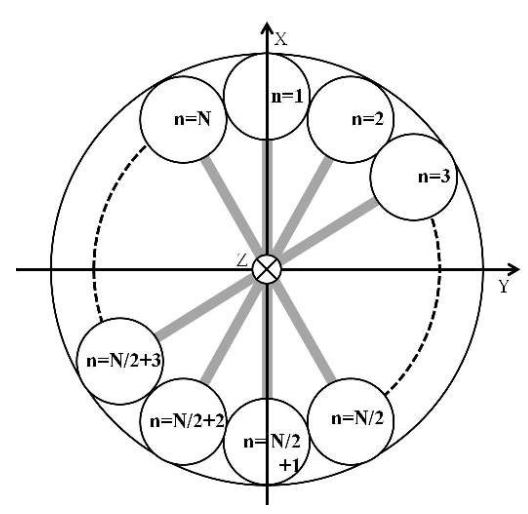

Fig. 2 Placement of rotors equiped on multi-rotors

ンプルな機体構造であり，メンテナンス性にも優れていることから，自律制御研究のプラットフォームとして効果 的であるためである.マルチロータ型へリコプタの中では四発ロータ機の自律制御に関する研究が最も盛んであ り，光の機動性を活かした制御技術や屋内での飛行を可能とする飛行技術などの研究が行われている(6)(7)(8)(9). 本

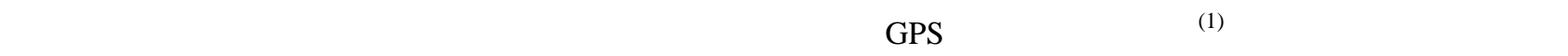
サによる自動着陸制御 ${ }^{(10)}$ を実現している .これらの研究においては高性能な自律制御の実現や機動性の追求に焦 点が当てられており，研究に特化した機体やカスタマイズされた高性能部品を採用することが主流となっている， しかしながら，構造がシンプルであり，メンテナンス性も良いという特徵から研究用途だけでなく，シングルロー 夕機に置き換わる産業用へリとしても十分に有効であると考えられ, 本研究では産業用プラットフォームとして マルチロータ機を活用することを目的としている．

産業用途に用いる際に重要となるのが前述のシングルロータ機における問題点の解消であり，本稿では各運用 に適した機体開発を実現するための設計手法を提案し，小規模な薬闵散布業務を対象とした仕樣を基に機体を実 現することで手法の有効性を示す . さらには , オーバースペックとなる専用部品の使用を控え , 汎用的な部品仕樣 を設計に考慮することでコストの低減化を狙う．本稿では，まず機体設計における要求仕樣について説明し，既 存機体での問題点と新たな機体開発の必要性について述べる．次に，具体的な機体設計手法について述べ，操縦 系統を設計するためのシミュレーションモデルを紹介する．最後に実現した機体の飛行実験を行うことで設計手 法の妥当性を検証する .

\section{2. 設 計 仕 様}

本稿では以下の小規模な薬斉散布業務における要求仕樣を取り上げ，マルチロータ機を適用することによりシ ングルロータ機での業務改善を図る。

1. 機体サイズ $1.0 \mathrm{~m}$ 末満, ロータ径 $0.3 \mathrm{~m}$ 末満, 積載重量 $1.0 \mathrm{~kg}$ 以上, 飛行時間 5 分以上を満足すること

2. 導入コストが同サイズの既存のシングルロータ型ヘリコプタよりも抑えられること

3. 産業用ヘリコプタの操縦性能を満足し, 既存機体のオペレータによる操縦が可能なこと

最初に既存製品について考えると，ホビー用途や産業用途として販売されているマルチロータ機には表 1 のよ うな機体か挙げられる. 国内での製品はまだなく，全て海外製品である . 要求仕樣からペイロード条件を満たして いる 2.5Eagleや MD4-1000 が対象となるが，二つの問題点が存在する . 一つはシングルロータ機よりも導入コス 卜が高いことであり，もう一つはカタログスペック上で操縦性能や制御性能か明らかとなっていないことである .

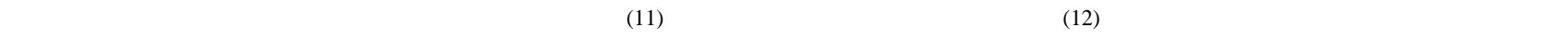
径がロータ径の二倍の球内に 30 秒間のホバリング状態を保持できること」として操作性能が規定されている .し かしながら，海外製品では自律制御がベースとなっており，操縦入力が制御系への目標値入力となるため，シング ルロータ機に比べて操縦指令に対する反応が鈍く，操作性が悪くなる．弚のため， シングルロータ機の飛行にな じんだオペレータほど操縦が難しくなる．以上から，本研究では上記仕樣を満足する機体の開発を目指す．

まず, 運用環境や仕樣変更によって変動のある仕樣 1 については, マルチロータ機の長所を活かした項目変化 
Table 1 Specifications of commercially available multi-rotors

\begin{tabular}{|c|c|c|c|c|c|}
\hline No. & Model number & Manufacturer & Num of rotors & Max size & Payload \\
\hline 1 & AR-Drone & Parrot & 4 & 0.45 & 0.0 \\
\hline 2 & X3D-BL & Ascending Technologies & 4 & 0.54 & 0.2 \\
\hline 3 & Falcon 8 & Ascending Technologies & 8 & 0.85 & 0.5 \\
\hline 4 & 330X-S QUADFLYER & Gaui & 4 & 0.43 & 0.0 \\
\hline 5 & Draganflyer X4 & Draganfly Innovations & 4 & 0.65 & 0.2 \\
\hline 6 & MK6 & MK-Kopter & 6 & 0.56 & 1.0 \\
\hline 7 & 2.5 Eagle & Service Drone & 8 & 0.95 & 4.0 \\
\hline 8 & MD4-200 & Microdrones & 4 & 0.70 & 0.2 \\
\hline 9 & MD4-1000 & Microdrones & 4 & 1.73 & 1.2 \\
\hline
\end{tabular}

に柔軟に対応した設計手法によって実現する．これにより設計期間の短縮と開発コストの低減化か望める．次に 先行研究のマルチロータ機においてコストが高くなっている要因がアーム部分に用いている専用設計品や高性能 部品にあることに着目し, 既存の産業用へリと信号を共通化し, 汎用的に用いられている部品を使用することに よってコストの低減化を図る. 先行研究において専用設計が必要な要因としては, 高機動性の実現ために制御信 号や演算周期を数百 $[\mathrm{Hz}]$ から数キロ $[\mathrm{Hz}]$ で取り扱い，高い安定性を得る必要があるからである．しかしながら， 高速な信号を扱うための MPU には高い処理能力を要し, 既存機体で用いられている部品や信号系とは一切の互換 性がなく，産業用途にはオーバースペックとなるため，コストの増大に繋がっていると考えられる．産業用途での 飛行はホバリングを中心とした低速な移動が主であり, 研究機ほどの高機動性を必要としない . 乥こで, 本研究 ではアーム毎の出力を標準化し，操舵における連成を考慮したロータ配置によって機体レベルでの安定性を高め， さらに角速度制御にはシングルロータ機と同樣のPI 制御を採用することにより，低周波信号での駆動を実現する． 駆動に用いる信号周期は $50[\mathrm{~Hz}]$ とし，アーム部分への入力は一般的な操縦入力に用いられている PWM 信号を用 いることで用用品との互換性と流用性を高める .

\section{3. 機 体 設 計}

本章ではマルチロータ機の設計手法について述べる．まず，機体形状に制約がない場合，三次元空間上にロータ

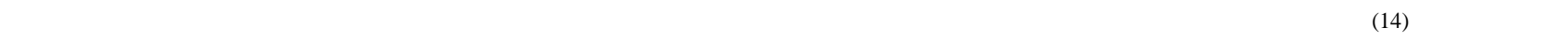
型ヘリコプタのようにロータを重ねて配置する方法 ${ }^{(15)}$, ロータ推力を水平方向に利用することによって推進力を 増加させる方法 ${ }^{(16)}$ などが挙げられる．しかしながら，産業用途への利用を目的とした場合，メンテナンス性を高 めるためにも機体構造は単純化された形状が望ましく, 万が一のトラブルの際にもシンプルな機体であるほど, 問 題点を早期に見つけることが可能となる . 乥こで , 各ロータを同一平面内 , 同一円周上に配置することを設計条 件とした . 光のときのロータ配置図と座標系を図 2 に示す . 市販製品や先行研究におけるマルチロータ機にもこ の形状に該当する機体が多いことから，十分に妥当性のある配置であると考えられる．機体前方に位置するロー タから時計回りに $n=1,2, \ldots, N$ と $\mathrm{N}$ 枚のロータ番号を定義し，機体前方を $\mathrm{X}$ 軸正方向，機体右方向を $\mathrm{Y}$ 軸正方 向，機体下方を Z 軸正方向として座標系を定義する.さらに設計手順の流れを図 3 へ示す. 求められる機体諸元 としては大きく四つの要素に分けられ, 運用範囲を飛行するために安全な機体サイズ, 搭載する貨物や機材の最 大積載量，飛行可能な最大時間，光して，開発および製造に関わるコストとなる．

\section{$3 \cdot 1$ ホバリング条件}

いま, 要求される貨物積載荷重を $W_{p}$, バッテリーを含む機体メインフレームの重量を $W_{b}$, アームの重量を $W_{a}$ ， ロータ枚数を $N$ とし，条件を標準状態 ${ }^{(13)}$ に換算すると，最大離陸重量 $W_{\max }$ は下式で与えられる .

$$
W_{\max }=\frac{293}{273+T_{a}} \frac{P_{a}-P_{w}}{999}\left(W_{b}+N W_{a}+W_{p}\right)
$$




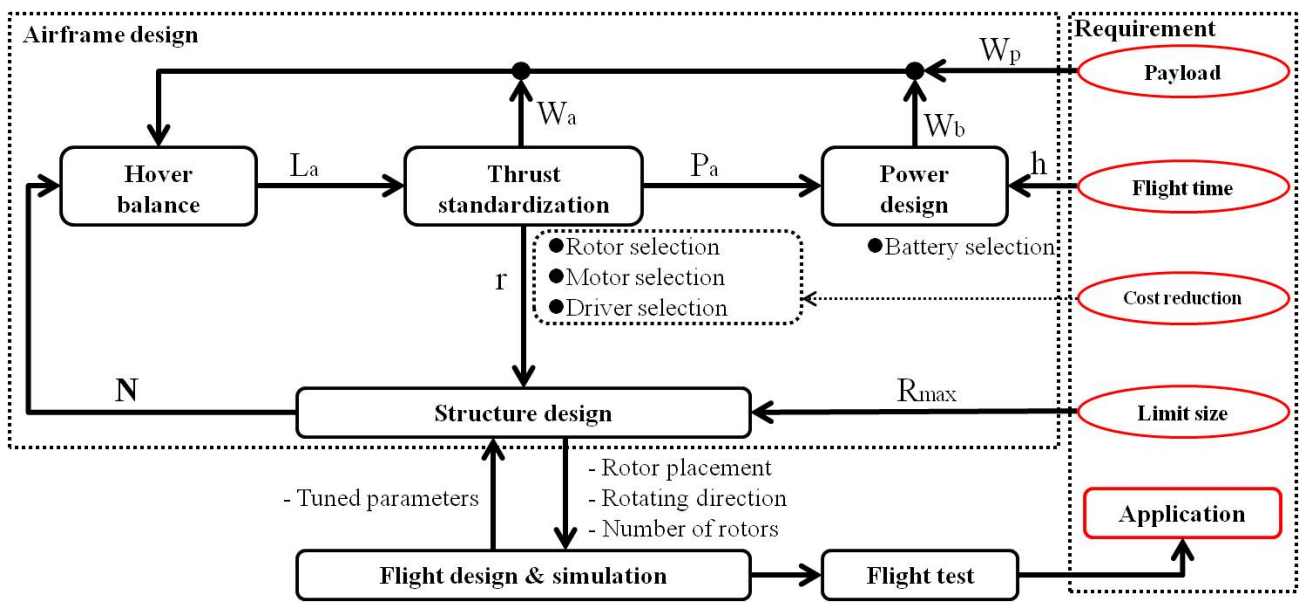

Fig. 3 Design flow of a Multi-rotor helicopter

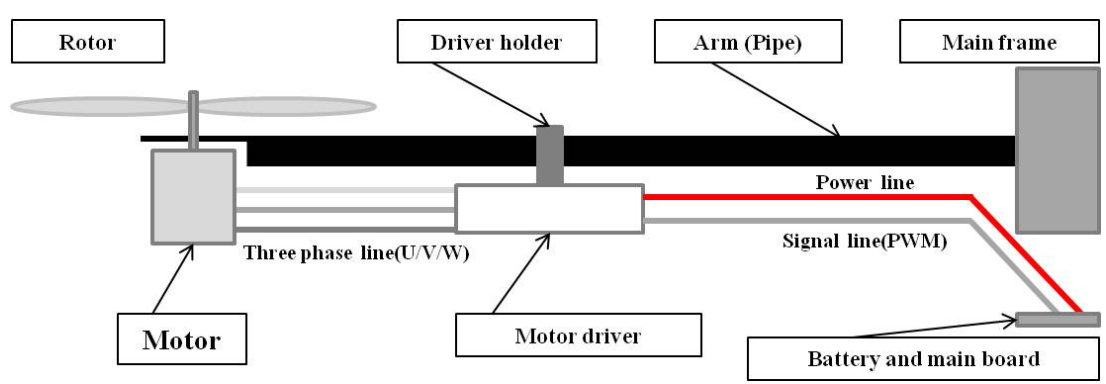

Fig. 4 Structure of an arm part

ここで, $T_{a}$ は温度 $\left[{ }^{\circ} \mathrm{C}\right], P_{a}$ は気圧 $[\mathrm{hPa}], P_{w}$ は水蒸気分圧 $[\mathrm{hPa}]$ を表す . ホバリング状態を維持するためのロータ 一枚あたりの推力 $L_{a}$ および最大推力 $L_{\max }$ は下式によって決定する .

$$
L_{a}=\frac{W_{\max }}{N}, \quad L_{\max }=(1+\alpha) L_{a}
$$

ただし， $\alpha$ は緊急時に危険回避を行う為の余剰推力であり，産業用途では 0.3 以上の值を設定する．

\section{$3 \cdot 2$ アームの設計とロータ推力の標準化}

続いて，アーム部分の設計を行う．アーム部分とはモータドライバ，モータ，ロータから成る機体を飛行させる ための揚力を担う場所である.アーム構造の一例として図 4 に示す構造が考えられ，複数本のアームをメインフ レームへ接続することでマルチロータ機は実現される．マルチロータ機ではアームの本数だけ部品点数が増える ため，この部分の汎用性を高めることで保守，メンテナンス性が向上し，低コスト化が可能となる．さらに既存 システムと同一の信号系を用いることで, 実績のある部品の使用を可能とする .

まず，各アームで使用されるモータについて最大出力值を基に選定する . 前章で求められたホバリング条件よ り各モータに必要な最大出力値は $\left(0.5 L_{\max }\right) /(1.366)[\mathrm{kW}]$ として与えられる. 出力が上がるほどモータ自身の重量 も増すため, 前節のホバリング条件を考慮しながら, 最大值以上の值を満足するような仕樣の物を選定する．

次に，モータドライバを選定する．ドライバにはトルク制御を行うものと回転数制御を行うのものが存在する が, 同一地点でのホバリングにおいても外乱や飛行環境によってロータにかかる負荷が異なるため, トルク制御 の場合は入力に対して回転数が一意に決まらないという問題点が発生する . 光こで, ホバリング回転数を中心と した回転数の変動と操縦入力值の関係が一意に決定できるように回転数制御のドライバを用い，さらにドライバ 部への入力信号を $50[\mathrm{~Hz}]$ の PWM 信号とすることで, 既存システムで実績のある幅広い部品選定が可能となる .

ロータは本来単体での使用を目的としており，マルチロータ機のような複数枚を同時に使用するケースは少な い.しかしながら，同一種のロータでも個体差や推力誤差が存在し，マルチロータ機の飛行特性に大きく影響す 

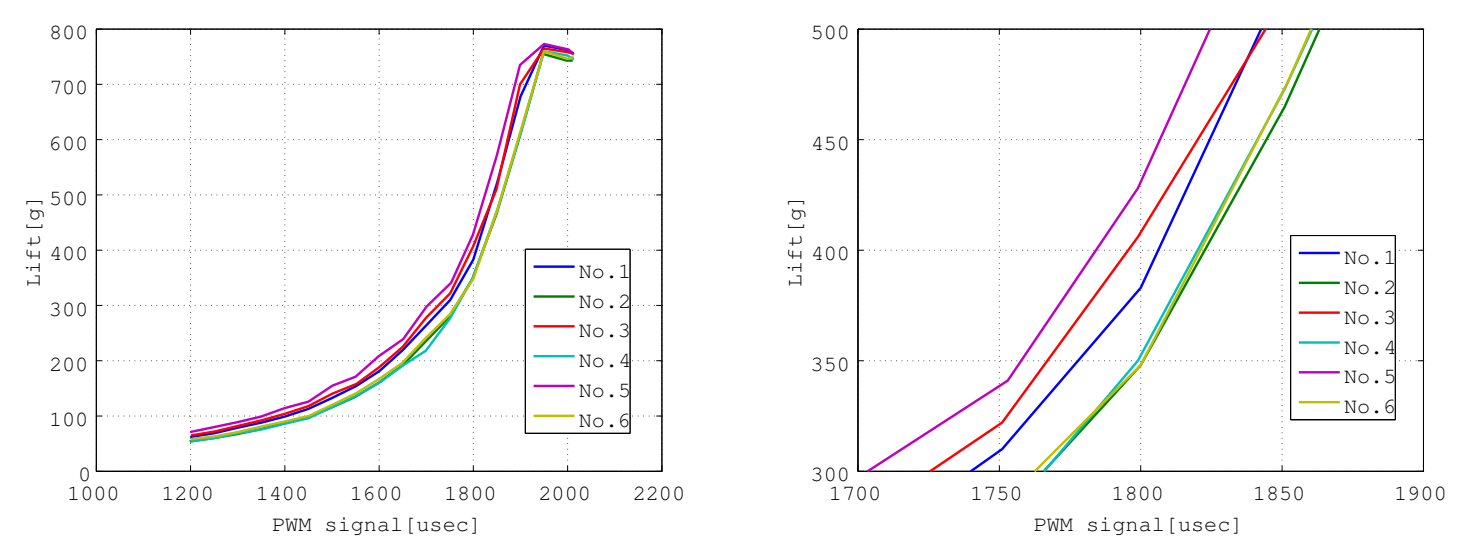

Fig. 5 Experimental result of measuring thrusts of each rotor

る . 図 5 に同一種のロータにおける左右三サンプル毎のドライバへの入力信号 [usec] から推力 $[\mathrm{g}]$ までの関係を取 得した結果を示す. 右図の拡大図は $1800[\mathrm{usec}]$ 付近を拡大した図であり，同一入力信号に対してロータ間で最大 $80[\mathrm{~g}]$ の推力差が生じているのか確認できる .この影響をなくす方法として , 高速な制御を用いて機体の安定化を 図る方法と事前の測定によって補正を行う方法が挙げられる . 低コス卜化を考えた場合，低速な制御周期での実 現か望ましいため, 後者の方法を採用し , 全てのロータにおける入力と推力の関係が同一となるような標準化を 行う. 各ロータにおいて標準となる入力 $u_{s}$ と推力 $F_{s}$ の関係を $F_{s}=g\left(u_{s}\right)$ とし , 各ロータにおける実際の出力が光 れに従うような関係を $f_{i}$ で定義すると，各アームへの入力 $u_{i}(i=1,2, \ldots, N)$ と各ロータ推力 $F_{i}(i=1,2, \ldots, N)$ の関 係は以下で表すことができる .

$$
F_{i}=g \circ f_{i}\left(u_{i}\right)
$$

一般的な回転数制御によるロータ駆動の場合， $g\left(u_{s}\right)$ は三次代数方程式による近似で与えられ，ホバリング時の推 力区間 $(1 \pm \alpha) L_{a}$ における誤差が $3 \%$ 以下となるようにパラメータを決定する . ホバリング時の釣り合いおよび飛 行時の操舵入力範囲において推力誤差が最小となる樣なパラメータの值を決定することで, 各ロータ間の誤差を 低減化することができる .

$$
g\left(u_{s}\right)=a_{3} u_{s}^{3}+a_{2} u_{s}^{2}+a_{1} u_{s}+a_{0}, \quad f_{i}\left(u_{i}\right)=b_{i} u_{i}+c_{i}
$$

\section{$3 \cdot 3$ パワーソース}

産業用途における電池の利用はこれまでニッケル系電池が主流であったが, リチウム系電池の発展が著しく，小 型軽量化が期待できる.さらに，メモリー効果が無いために，短時間の飛行の度に充放電を繰り返すマルチロー 夕機では使い勝手の向上にも辌がるため, リチウム系電池を採用する .

電池容量は設計仕樣で与えられる飛行時間に大きく影響するが, 飛行の状態によっで消費電力が異なるため, 厳 密な飛行時間の導出は困難である．しかしながら，散布業務や空撮業務等の産業用途で使用する飛行はほとんど がホバリング付近であり，また，飛行に必要な電力のほとんどがアーム部分で消費されるため，下式の近似によっ て電池容量 $C_{b}$ を決定することができる .

$$
C_{b} \geq k N P_{a} h
$$

ただし，ホバリング回転数て駆動しているアーム一本あたりの消費電力を $P_{a}[\mathrm{~W}]$, 飛行時間を $h[\mathrm{~h}]$, 安全係数を $k$ とし , ホバリング近辺の業務においては 1.5 として設計する .さらに上記容量とエネルギー密度からバッテリー重 量が求まるので, 再度ホバリング条件を満足しているかを判断する。

\section{4 機体およびロー夕径}

次に機体サイズに関する設計仕樣について述べる，機体サイズを考える上で重要となってくるのがロータ径で ある . 揚力を大きく得るための手段として , 径を大きくする方法とピッチ角を大きくする方法が考えられる . 市 


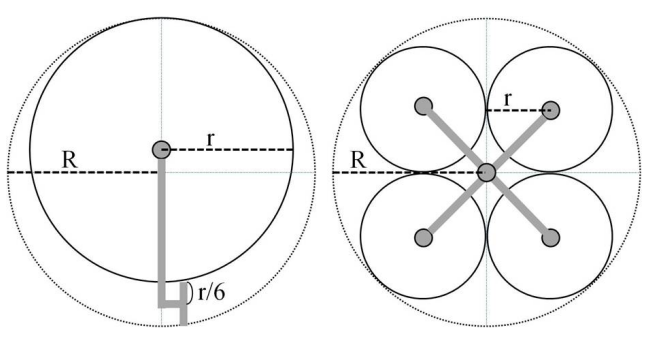

Fig. 6 Image of single and multi rotor helicopters
Table 2 Parameters of single and multi rotor helicopters

\begin{tabular}{|c|c|c|c|c|}
\hline Type & $N$ & $R$ & $S_{r}$ & $\sigma$ \\
\hline Single Rotor & 1 & $(1+1 / 6) r$ & $\pi r^{2}$ & 0.661 \\
\hline Multi Rotor & 4 & $(1+\sqrt{2}) r$ & $4 \pi r^{2}$ & 0.686 \\
\hline Multi Rotor & 6 & $(1+2) r$ & $6 \pi r^{2}$ & 0.667 \\
\hline Multi Rotor & 8 & $(1+2 / \sqrt{2-\sqrt{2}}) r$ & $8 \pi r^{2}$ & 0.613 \\
\hline Multi Rotor & $\mathrm{N}$ & $\left(1+1 / \sin \frac{\pi}{N}\right) r$ & $N \pi r^{2}$ & $\rho N /\left(1+1 / \sin \frac{\pi}{N}\right)^{2}$ \\
\hline
\end{tabular}

販の汎用的なロータを用いることを考えると，同一径のロータでピッチ角が複数の仕樣を持つものは少なく，ピッ チ角を変更するよりもロータ径を変更する方が幅広い設計仕樣に対応できる．ロータ径が大きいほど得られる最 大揚力は大きくなることから，同一機体サイズにおいてロータ回転面積が大きいものほど飛行に使用できる揚力 の幅は広がる.さらに, 回転翼機の場合, バッテリーの電気エネルギーがモータ, ロータによって推力へと変換さ れるため，揚力部分で使用可能なエネルギーが多いほど有利となる．これらを踏まえて，機体全面積 $S_{b}$ における 回転面積 $S_{r}$ および揚力に用いられるエネルギ一効率 $\rho$ から表される評価パラメータ $\sigma$ を導入する .

$$
\sigma=\rho \frac{S_{r}}{S_{b}}=\rho \frac{N r^{2}}{R^{2}}
$$

ただし , 機体半径を $R$, ロータ半径を $r$ とした . 制御基板での消費電力や各部でのエネルギーロスについてはモー 夕駆動での消費電力に比へてて分に小さいため 0 と仮定する . 同一平面内で最大のロータ径を持つ機体としてはシ ングルロータ機であるが, シングルロータ機はメインロータの回転による反トルクを打ち消すためにテールロー タが必要となる . 兴の概形を図 6 に示す . テールロータはメインロータ径の約五分の一から六分の一の大きさで設 計され，メインロータの $10 \%$ 程度の出力を消耗する .よって $, N=1, R=(7 / 6) r, \rho=0.9$ として , シングルロー 夕機の評価パラメータは 0.661 となる . マルチロータ機の場合 , 半径 $R$ に内接する $N$ 個の円が最大ロータ径とな るので $R=\left(1+1 / \sin \frac{\pi}{N}\right) r$ が成り立ち，ロータ回転の全てが揚力として利用されることから $\rho=1.0$ となる.各機 体の比較を表 2 人示す. シングルロータ機と比べても遜色はなく， $N=4$ において最大となり，ロータ数か増える 毎に少しずつ効率は低下する .このことからロータ径に制限を受けない要求仕樣の場合はロータ数を少なく設計 する方が有利となる．

いま, 運用範囲等から要求仕樣において機体全長が制限される場合, 許容最大值を $R_{\max }$ とすると, 機体半径 $R$ に与えられる条件は以下で表される .

$$
2 R \leq R_{\max }
$$

要求仕樣において $R_{\max }$ が明記されない場合は, ロータ径を基に $R_{\max }=8 r$ として決定する .さらに， $\left(R_{\max }-4 r\right)$ が機体中央の制御基板やペイロードを搭載する範囲であり，搭載物の大きさから制限を受ける場合は，機体半径に よって調整を行う．以上より，要求仕樣を満足する機体形状 $R$ を決定することができる .上述の設計手順は, 効率 の最も良い $N=4$ を初期条件とし, 各条件に合致しない場合, $N$ を増加させながら設計ループを回すことで, 要 求仕樣を満足する機体を設計することが可能となる.

\section{4. 飛行 設 計}

\section{$4 \cdot 1$ 飛行原理と回転方向}

図 7 にマルチロータ型ヘリコプタの飛行原理を示す.$X$ 軸を中心として左右に配置されているロータの推力差を 用いてローリングを， $Y$ 軸を中心として前後に配置されているロータの推力差を用いてピッチングを，右回転と左 回転のモーメント差を用いてヨーイングを, 全ロータの推力を等しく変化させることで上昇下降を行う. 表 1 に おける同一平面内，同一円周上にロータ配置を持つ機体について考えると，ロータの回転方向には図 8 のような 二通りのパターンに分けられる . 向かい合うロータが同一方向に回転している場合と逆方向に回転している場合 である .いま，一対のロータが回転数 $\omega$ で回転していると仮定する . 操舵によって与える回転数の変動量を $\Delta \omega$ とすると，各ロータの回転数は $\omega+\Delta \omega ， \omega-\Delta \omega$ で表される.この一対のロータが同一方向に回転している場合， 


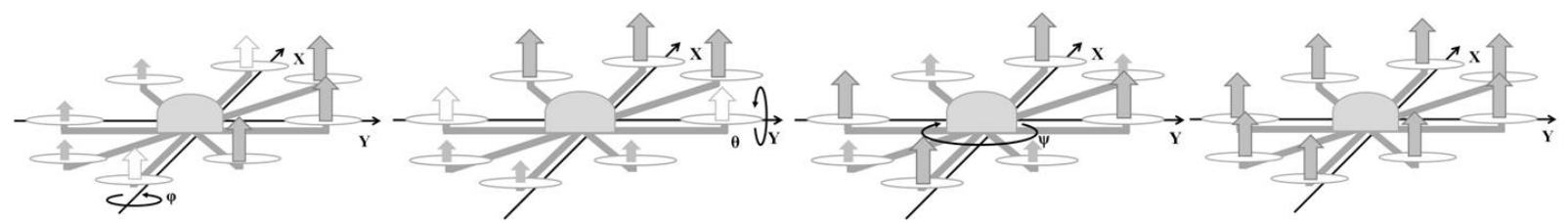

Fig. 7 Flight principle of multi-rotors

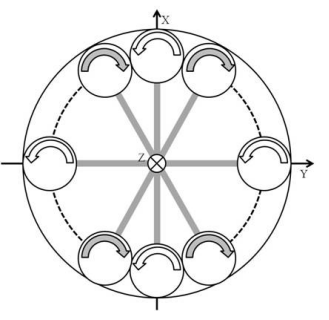

(a) $\mathrm{N}=4 \mathrm{n}$

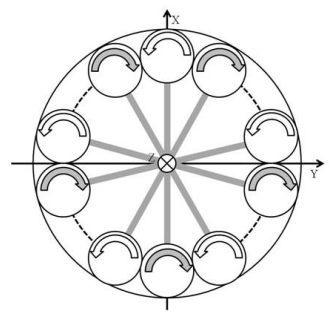

(b) $\mathrm{N}=4 \mathrm{n}+2$

Fig. 8 Rotor placement of previous products

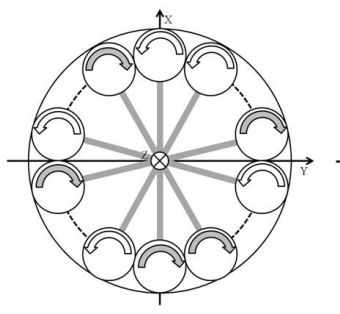

(a) $\mathrm{N}=4 \mathrm{n}+2$

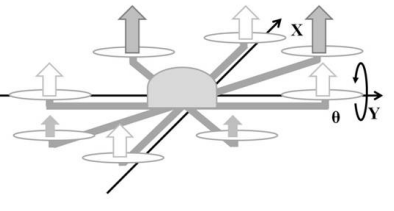

(b)Pitching principle
Fig. 9 Improved rotor placement and pitching principle

回転面内のモーメントは相殺されるため，回転面に垂直方向のモーメントのみが機体の運動に寄与する．しかし， 逆回転の場合, 回転数の変動 $2 \Delta \omega$ に相当するロータ回転面内のモーメントが相殺されず, 二軸のモーメントが発 生する . この問題は図 $8(\mathrm{~b})$ のようにロータ数が $N=4 n+2(n=1,2, \cdots)$ で表される際に , 左右交互にロータを配 置することで生じる . 各対で生じるモーメントをロータ全体で釣り合わせることによって上記の影響を無くすこ とが可能であるが, $N=4 n+2$ におけるピッチング時の影響を取り除くことはできない.さらに，本研究のよう に $50 \mathrm{~Hz}$ と低速な周期で制御を行う場合は, 各ロータ間での誤差も生じやすくなるため, 逆回転による連成の影響 はより大きく現れる .

これらの問題を解決するため, 本研究ではロータ枚数が $N=4 n+2$ である際のロータ回転方向を図 9(a)のよう に与えた .これは図 8(b) における $X$ 軸上を除いた右反面に配置されたロータの回転方向を逆転させることで実現 でき, $X$ 軸上以外の向かい合うロータが同一回転方向となっている .さらにピッチング操作を行う際に与える回転 数の変動は図 9(b) のように $X$ 軸上以外のロータに与えることとした . こうすることによって操舵に寄与するロー 夕は同じ回転方向同士が対となるため, 図 8(b) において生じていたピッチング時の連成を低減化することが可能 となり，操縦性能の良い機体を実現できる．

\section{$4 \cdot 2$ 操縦指令とロータミキシング}

ここでは , 各軸の操縦入力值と各ロータへの指令值を関係付ける . 慣例に合わせてローリング , ピッチング , ヨー イングを行う操縦をエルロン, エレベータ, ラダーと定義し, 全体の推力変化によって上昇下降を行う操縦をス ロットルとする . 各軸の操縦入力を $\boldsymbol{M}=\left[M_{A i l}, M_{E l e}, M_{R u d}, M_{T h r}\right]$ として以下で定義する.

$$
\begin{aligned}
S_{A i l} M_{A i l}+\tau_{A i l}+u_{\phi} & =(R-r) \sum_{i=1}^{N}\left(F_{i} \sin \frac{2 \pi i}{N}\right) \\
S_{E l e} M_{E l e}+\tau_{E l e}+u_{\theta} & =(R-r) \sum_{i=1}^{N}\left(F_{i} \cos \frac{2 \pi i}{N}\right), \quad i \neq 1, N / 2+1 \quad(N=4 n+2) \\
S_{\text {Rud }} M_{\text {Rud }}+\tau_{R u d}+u_{\psi} & =\left\{\begin{array}{l}
\sum_{i=1}^{N}\left(Q_{i}(-1)^{i-1}\right), \quad N=4 n \\
Q_{1}+\sum_{i=2}^{N / 2}\left(Q_{i}(-1)^{i}\right)+\sum_{i=N / 2+1}^{N}\left(Q_{i}(-1)^{i-1}\right), \quad N=4 n+2
\end{array}\right. \\
S_{T h r} M_{T h r}+\tau_{T h r} & =\sum_{i=1}^{N}\left(F_{i}\right)
\end{aligned}
$$

ただし,$Q_{i}(i=1,2, \ldots, N)$ は各ロータに生じるトルクを表し，推力 $F_{i}$ が与えられたときの回転数から求まる . $\boldsymbol{S}=\left[S_{A i l}, S_{E l e}, S_{R u d}, S_{T h r}\right]$ および $\boldsymbol{\tau}=\left[\tau_{A i l}, \tau_{E l e}, \tau_{R u d}, \tau_{T h r}\right]$ は操縦感度とトリムを表し，オペレータ技能とフライト環 境に応じて調整を行う $. \boldsymbol{u}=\left[u_{\phi}, u_{\theta}, u_{\psi}\right]$ は後述するジャイロフィードバック制御による信号である . 式 (8) から式 
(11) を $F_{i}$ について解くことで操縦指令值に対応した各ロータ推力を求めることができる $. N>4$ のときは条件数 よりも未知数の方が多くなるため, 各パラメータは誤差ノルムを最小とする最適解を用いる . このとき求まる值 は標準化された推力值となるので, 式 (3) を用いることで各ロータへの入力值が求まる.

$4 \cdot 3$ ジャイロフィードバック制御

シングルロータ機では人が反応できない機体の振動やノイズによる高周波の姿勢変動を除去するため, スタビ ライザ機構によるロール，ピッチ方向の安定化とヨー方向に取り付けられたジャイロセンサを用いた角速度制御 によって安定化を実現している．しかし，マルチロータ機の場合，スタビライザ機構を有しないため，三軸のジャ イロセンサを用いた角速度制御を必要とする . 乥こで, ドライバへの入力周期に合わせた $50[\mathrm{~Hz}]$ の PI 制御を採用 し，ロール，ピッチ，ヨーの各軸に対してジャイロフィードバック制御を構成する．ロール，ピッチ，ヨーの各方 向を $\phi, \theta, \psi$ で表すと，制御入力 $\boldsymbol{u}=\left[u_{\phi}, u_{\theta}, u_{\psi}\right]$ は下式で与えられる.

$$
\boldsymbol{u}=K_{p} \boldsymbol{\omega}(t)+K_{i} \int \boldsymbol{\omega}(t) d t
$$

ただし， $K_{p}$ および $K_{i}$ は PI 制御の定数ゲインを表し，非対角要素は 0 である．制御入力が大きくなるほど，操縦 感がなくなり，慣れたオペレータほど違和感を感じるため, 制御入力による推力変化の上下限をホバリング推力 の $10 \%$ として制限する。

\section{$4 \cdot 4$ 姿勢モデル}

機体を実現するにあたりパラメータが適切な範囲に収まっていない場合，暴走や墜落の危険がある．光こで, 前 節の入力モデルに従った操縦入力を与えた時に機体の姿勢がどのように変化するかを事前のシミュレーションに よって検証し，パラメータを調整しておくことで安全に効率の良い機体実現が可能となる．

いま，機体の角速度べクトルを $\boldsymbol{\omega}=\left[\begin{array}{lll}\dot{\phi} & \dot{\theta} & \dot{\psi}\end{array}\right]^{T}$, 慣性モーメントを $\boldsymbol{I}=\left[\begin{array}{lll}I_{x x} & I_{y y} & I_{z z}\end{array}\right]^{T}$ とし, そのときの外力を $\boldsymbol{T}=\left[\begin{array}{lll}T_{\phi} & T_{\theta} & T_{\psi}\end{array}\right]^{T}$ で定義すると，オイラーの運動方程式より各軸周りの回転運動は以下で表される．

$$
\begin{aligned}
& I_{x x} \ddot{\phi}=\dot{\theta} \dot{\psi}\left(I_{y y}-I_{z z}\right)+T_{\phi} \\
& I_{y y} \ddot{\theta}=\dot{\psi} \dot{\phi}\left(I_{z z}-I_{x x}\right)+T_{\theta} \\
& I_{z z} \ddot{\psi}=\dot{\phi} \dot{\theta}\left(I_{x x}-I_{y y}\right)+T_{\psi}
\end{aligned}
$$

ここで, 機体に働く外力は操縦入力によるものと各ロータの回転から生じるジャイロモーメントによるものとの 合力であることから，ロータのモーメントを $J$, 回転数を $\Omega_{i}$ として , 下式で表される .

$$
\begin{aligned}
& T_{\phi}=S_{\text {Ail }} M_{\text {Ail }}+\tau_{A i l}+u_{\phi}-J \dot{\theta} \sum_{i=1}^{N}\left(\Omega_{i} \sin \frac{2 \pi i}{N}\right) \\
& T_{\theta}=S_{E l e} M_{E l e}+\tau_{E l e}+u_{\theta}+J \dot{\phi} \sum_{i=1}^{N}\left(\Omega_{i} \cos \frac{2 \pi i}{N}\right) \\
& T_{\psi}=S_{R u d} M_{R u d}+\tau_{R u d}+u_{\psi}
\end{aligned}
$$

以上で表されるモデルによってシミュレーションを行う.ただし，3.2 節において測定された実験結果を基に入力部 のダイナミクスは一次遅れとして近似しておく.シミュレーションではホバリング状態からの操縦入力 $\pm 100[\mathrm{usec}]$ に対して , 入力から 1 秒以内の姿勢変動が $\pm 7[\mathrm{deg}]$ 末満となるようにパラメータの調整を行う .

\section{5. マルチロータ機の実現}

\section{1 機体諸元}

与えられた要求仕樣に対して, 前節までの設計手法を用いてマルチロータ機を実現した . 機体の実装に用いた 汎用部品を表 3 人, 機体仕樣および設計に用いたパラメータを表 4 へ, 機体の全体像を図 10 へ示す.アーム部分 をはじめ,一般的な汎用製品によって構成したことで, メンテナンス性の向上と低コスト化か実現されており，こ れまでの機体と同樣の $50[\mathrm{~Hz}]$ の駆動信号による実現を果たしているため, リソースの再活用も可能となっている. 


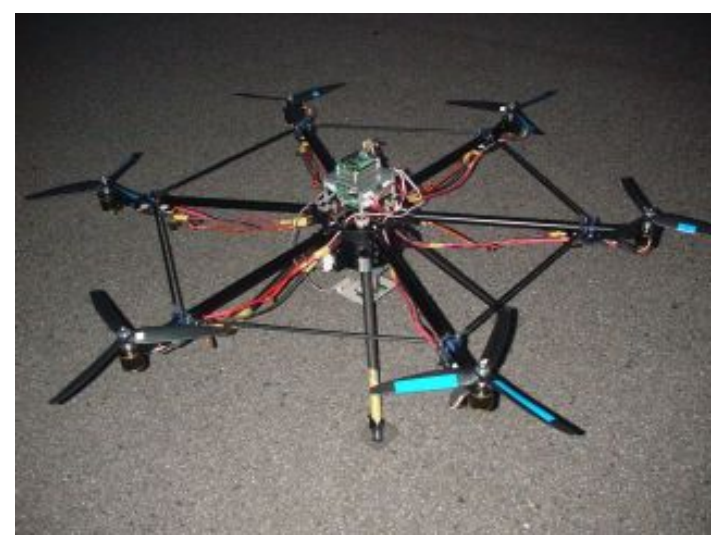

Fig. 10 Overview of the multi rotor
Table 3 Commercial components of the multi rotor

\begin{tabular}{|c|l|c|}
\hline Parts & Manufacturer & Model number \\
\hline Motor & SCORPION & S2215-22 \\
\hline Driver & Hacker Motor & MASTER SPIN33 \\
\hline Rotor & GWS & EP1060 \\
\hline Radio transmitter & Futaba & T8FGS \\
\hline Radio receiver & Futaba & R6208SB \\
\hline Battery & HIROBO & Lepton EX battery \\
\hline CFRP pipe & HIROBO & LEX 0304-071 \\
\hline Gyro sensor & EPSON TOYOCOM & XV3500 \\
\hline
\end{tabular}

Table 4 Specifications and parameters of the designed multi rotor

\begin{tabular}{|c|l|l|c|c|c|c|c|c|c|c|c|}
\hline Size & $0.97[\mathrm{~m}]$ & $a_{0}$ & $-9.5207 \mathrm{e}+003$ & $b_{1}$ & 1.10 & $c_{1}$ & -198 & $K_{p \phi}$ & 4.0 & $S_{\text {Ail }}$ & 0.20 \\
\hline Max payload & $1.0[\mathrm{~kg}]$ & $a_{1}$ & $2.0364 \mathrm{e}+001$ & $b_{2}$ & 1.00 & $c_{2}$ & 0 & $K_{i \phi}$ & 6.0 & $S_{\text {Ele }}$ & 0.34 \\
\hline Flight time & $5.5[\mathrm{~min}]$ & $a_{2}$ & $-1.4489 \mathrm{e}-002$ & $b_{3}$ & 1.11 & $c_{3}$ & -227 & $K_{p \theta}$ & 4.0 & $S_{\text {Rud }}$ & 0.69 \\
\hline Num of Rotor & 6 & $a_{3}$ & $3.4579 \mathrm{e}-006$ & $b_{4}$ & 1.00 & $c_{4}$ & -2 & $K_{i \theta}$ & 6.0 & $S_{T h r}$ & 0.75 \\
\hline Rotor diameter & $0.25[\mathrm{~m}]$ & - & - & $b_{5}$ & 0.98 & $c_{5}$ & -3 & $K_{p \psi}$ & 8.3 & - & - \\
\hline Hovering revolution & $4500[\mathrm{rpm}]$ & - & - & $b_{6}$ & 1.00 & $c_{6}$ & -2 & $K_{i \psi}$ & 0.0 & - & - \\
\hline
\end{tabular}

\section{2 フライト 実験}

続いて，実現したマルチロータ機を用いた飛行実験を行った．飛行環境での機体姿勢を取得するため，先行研 究で開発した姿勢センサ ${ }^{(17)}$ を搭載した . 飛行内容は, 離陸後, まっすぐに上昇し, 約 2 分間のホバリングを行っ た後，まっすぐ降下し，着陸した．炎のときの操縦入力を図 11(a)に，角速度を図 11(b)に，姿勢角を図 11(c) に 示す. 図 11(a)の Throttle 入力より $t=20[\mathrm{~s}]$ において離陸が行われ， $t=170[\mathrm{~s}]$ 付近で着陸が行われている. 間のホバリング時の操舵入力を確認すると，ロール，ピッチ方向の操舵が士 100[usec] となっており，大きな操舵 を行うことなく安定したホバリングが実現できているのが分かる. 図 11(b) における 165 秒付近で大きな角速度が 生じているが， これは固い地面への着陸であったため，瞬間的に大きな振動が加わることでセンサに現れたノイ ズ成分である . フライト中は終始 $20[\mathrm{deg} / \mathrm{sec}]$ 程度の角速度を保っており，姿勢を崩すような動きがないことが分 かる . 次に図 11(c) の姿勢角を確認すると，今回搭載した姿勢センサ出力の計測範囲が-179〜180[deg]であったた め, $t=55,85,120[\mathrm{sec}]$ 付近でヨ一角のデータに飛びが見られるが , 実際の機体の動きは連続的な運動である. 機 体の方向を確認するため, ゆっくりとしたヨー方向の入力を与えているが, 弚のときも機体姿勢が大きく傾くこ とは見られない.さらに, ロール角及びピッチ角が終始士 $10[\mathrm{deg}]$ 程度に収まっていることから, 安定したホバリ ングが行えており, 十分な操作性を実現できていることが分かる．今回開発した機体に用いた部品はほとんどが 黑色であり, さらに機体が前後左右に対称であるため, 錯覚によって飛行中の方向が掴みにくいという視認性の問 題が生じた . シングルロータ機においてはテールロータが視認性向上の役割も果たしているため, この問題は機 体のアームや脚部に色の変化を与えたり，機首後方のデザインを改善することで解消が可能である .

\section{$5 \cdot 3$ シミュレーションモデルの検証}

本来と手順は異なるが, 導出したシミュレーションモデルが妥当であるかを検証するため, ホバリング時の実験 データとシミュレーション結果との比較を行った .シミュレーションモデルは , 式 (13)〜式 (18)に対して，N=6， ロータ配置を $4 n+2$ のパターンに設定し , 表 4 で表されるパラメータを用いた . ホバリング状態におけるシミュ レーションと実験データの比較結果を図 12 に示す.

図 12(a)における50 秒から53 秒付近や図 12(b)の68 秒から 70 秒付近, 両図の 92 秒から 94 秒付近にかけての 


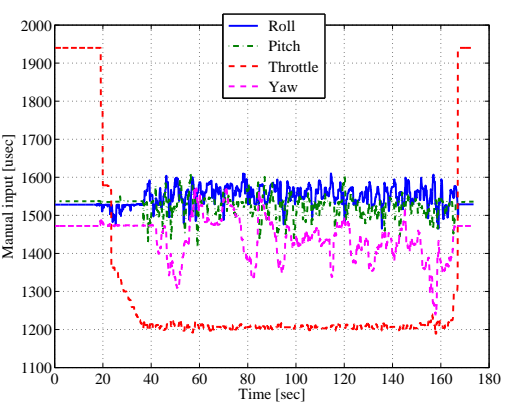

(a)Operating inputs

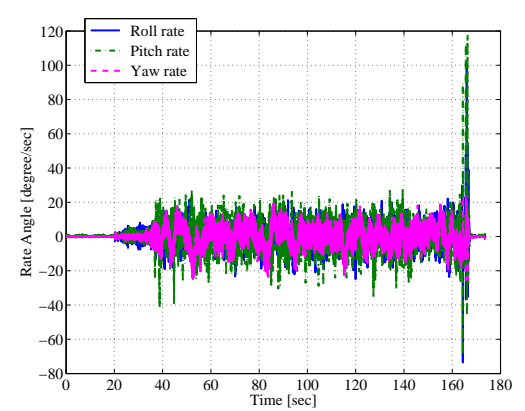

(b)Angular rates

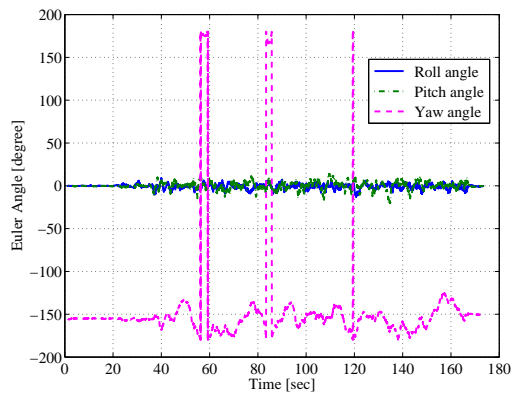

(c)Euler angles

Fig. 11 Experimental result of hovering flight

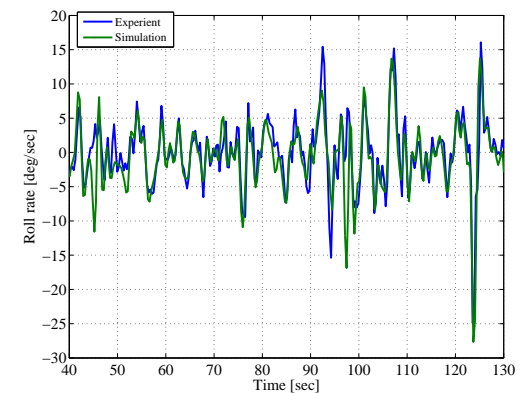

(a)Roll

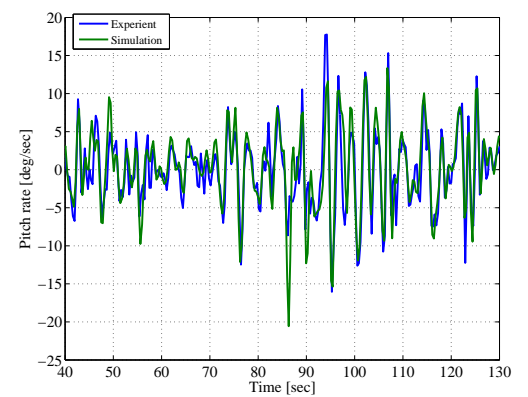

(b)Pitch

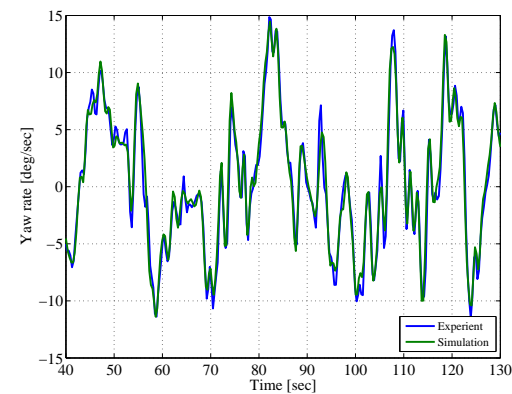

(c)Yaw

Fig. 12 Experimental and simulated result of angular rate

データにおいて両者の間に誤差が生じているものの全体の傾向は一致しているのか確認できる . 実験機ではアーム 部分に振動が生じていたため, 図 12(a)の 50 秒から 53 秒付近のようなハンチンク現象が生じており，シミュレー ションモデルでは機体の振動を考慮していなかったために，適切に表現できなかったと考えられる．しかしなが ら，機体の振動はアーム接合部を強固にすることや防振材を組み込むことで低減化が期待できる．

本稿の仕樣では 6 発ロータ機であったが，手順を一般化して導出し実現機体とよく一致していることから，同 形状の多発ロータ機に対しても十分に妥当性のあるモデルであると考えることができる．これより，新規機体を 開発する際のシミュレーションが容易となり，十分にパラメータの適切さを検証した上で実装することが可能とな る.これまでの新規機体開発において, パラメータが末調整の段階で初回飛行を行わざるを得なかった状況が改 善されることは安全面でも大きなメリットとなる .

\section{6. 結 言}

本稿では, シングルロータ機に代わる存在としてマルチロータ機に着目し, 要求仕樣を基とした汎用性のある 設計手法について述へ，機体の実現によって产の有効性を示した .さらに，設計には可能な限り汎用品を用いた ことで，イニシャルコストの低減化とオーバースペックである専用部品の削減を果たし，操縦パラメータを導入 することによってシングルロータ機と同樣の操縦性能を実現した . これによってシングルロータ機が抱えていた 適切な運用とコストダウンが図れ，より幅広い産業への投入が可能となる.

本研究グループでは, 本稿で開発した多発ロータ機を用いて 2011 年 3 月の東北大震災における被災地の空撮に も成功を収めており ${ }^{(18)}$ ，このことからも産業用途として十分な飛行性能を有していることがわかる．今後は小規 模な農薬散布を含め，樣々な業務においての実用化を目指す予定である .

$$
\text { 文献 }
$$

(1) K. Nonami, F. Kendoul, S. Suzuki, W. Wang, D. Nakazawa, Autonomous Flying Robots - Unmanned Aerial Vehicles and Micro Aerial Vehicles(2010), Springer Japan. 
(2) B. Mettler, M.B. Tischler, and T. Kanade, "System identification modeling of a small-scale unmanned rotorcraft for flight control design”, Journal of the American Helicopter Society, Vol. 47, No. 1 (2002), pp. 50-63.

(3) P. Abbeel, A. Coates, M. Quigley, and A.Y. Ng, "An application of reinforcement learning to aerobatic helicopter flight", Advances in Neural Information Processing Systems 19: Proceedings of the 2006 Conference(2007), pp. 1-8.

(4) 辛振玉, 藤原大悟, 羽沢健作, 野波健蔵, “ラジコンヘリコプタの姿勢制御・ホバリング制御”, 日本機械学会論文集 C 編, Vol. 68, No. 675 (2002), pp. 3284-3291.

(5) 藤原大悟, 辛振玉, 羽沢健作，野波健蔵 “自律小形無人ヘリコプタ $\mathrm{H}$ ×ホバリング制御および誘導制御”，日本機械学会 論文集 C 編，Vol. 70 ，No. 694 (2004)，pp. 1708-1714.

(6) P. Castillo, A. Dzul, and R. Lozano, "Real-time stabilization and tracking of a four-rotor mini rotorcraft", Control Systems Technology, IEEE Transactions on, Vol. 12, No. 4 (2004), pp. 510-516.

(7) McKerrow, P., "Modelling the Draganflyer four-rotor helicopter", Proceedings of the 2004 IEEE International Conference on Robotics and Automation, New Orleans, LA(2004), pp. 3596-3601.

(8) Hoffmann, G.M. and Huang, H. and Waslander, S.L. and Tomlin, C.J., "Quadrotor helicopter flight dynamics and control: Theory and experiment", Proceedings of the American Institute of Aeronautics and Astronautics Guidance, Navigation, and Control Conference, Vol. 4(2007), pp.44.

(9) Bouabdallah, S. and Murrieri, P. and Siegwart, R., "Design and control of an indoor micro quadrotor", Proceedings of the 2004 IEEE International Conference on Robotics and Automation, New Orleans, LA(2004), Vol. 5(2004), pp. 4393-4398.

(10) 岩倉大輔, 王偉, 野波健蔵, HALEY Mark, “4 発ロータ式 MAV の可動式外界センサシステムによる高精度着陸”, 日本 機械学会論文集 C 編，Vol. 76，No.761 (2010)，pp. 61-68.

(11) 日本産業用無人航空機協会回転翼委員会, “産業用無人ヘリコプターによる観測・空撮作業等実施のための安全の手引き”, 日本産業用無人航空機協会 (2008).

(12) 日本産業用無人航空機協会回転翼委員会, “産業用航空機安全基準「回転翼機・無人地帯用」”, 日本産業用無人航空機協会 (2010).

（13）社団法人日本規格協会, “JIS HB 標準化 2008”, 社団法人日本規格協会 (2008) .

(14) Borrmann, A. and Ji, Y. and Wu, IC and Obergrießer, M. and Rank, E. and Klaubert, C. and Günthner, W., "ForBAU-The virtual construction site project", Proceedings of the 26th International Council for Building World 78 Conference on Managing IT in Construction(2009).

(15) Prior, S.D. and Karamanoglu, M. and Odedra, S. and Foran, T. and Erbil, M.A., "Development of a co-axial tri-rotor UAV", 24th Bristol International Unmanned Air Vehicle Systems Conference, 30 March-1 April,University of Bristol(2009), pp. 15.1-15.16.

(16) Salazar, S. and Romero, H. and Lozano, R. and Castillo, P., "Modeling and real-time stabilization of an aircraft having eight rotors", Journal of Intelligent and Robotic Systems, Vol. 54(2009), pp. 455-470.

(17) 田原誠, 鈴木智, 野波健蔵, “小型軽量汎用性を特徵とする小型姿勢センサの開発”, 日本機械学会論文集 C 編, Vol. 77, No. 781 (2011), pp. 3386-3397.

(18) NONAMI LABORATORY, “MAV/UGV Nonami Lab.”, http://mec2.tm.chiba-u.jp/ nonami/research/mav/home.html(参照日 2011 年 12 月 1 日). 